УДК $341.1 / 8$

Н. Ю. Климович

\title{
ПРОЦЕС СТАНОВЛЕННЯ МІЖНАРОДНО-ПРАВОВОГО РЕГУЛЮВАННЯ РЕГІОНАЛЬНОЇ ЕКОНОМІЧНОЇ ІНТЕГРАЦІЇ ЄВРОПЕЙСЬКОГО СОЮЗУ
}

Постановка проблеми в загальному вигляді. В умовах інтенсифікації глобалізації та міжнародної інтеграції й появи гібридних систем правового регулювання в економічних інтеграційних об’єднаннях виникає потреба в аналізі внеску регіональних економічних інтеграційних об'єднань в становленні міжнародно-правової системи. Особливо актуальним це є з огляду на те, що на сьогодні Україна прагне долучитися до світового процесу економічної інтеграції, адже це відкриє нові економічні можливості та нові ринки. Але розвиток такого роду співробітництва в рамках регіональних економічних інтеграцій базується на організаційних та правових механізмах, що забезпечує ефективну роботу системи. Регіональна економічна інтеграція на сьогодні одне з найважливіших явищ світового господарювання, що містить безліч аспектів міжнародного співробітництва у сфері транснаціоналізації виробничого процесу та обміну капіталом та ресурсною базою. Ці аспекти потребують наднаціонального регулювання та більш тісної правової співпраці. На теренах сучасної Європи протягом останніх 100 років відбувався процес інтеграції, що переросло у створення Європейського Союзу (далі - ЄС). Україна наразі прагне до зближення з $\mathrm{CC}$ з метою повноцінної інтеграції та членства в ЄС. Відповідне прагнення нещодавно було закріплене в преамбулі Конституції України як стратегічний курс нашої держави. Відповідно до цього важливим залишається необхідність проаналізувати процес інтеграції на європейських теренах, зародження думки про економічну інтеграцію як ефективного механізму міжнародної співпраці, та досвід держав, що долучилися до цього процесу значно раніше за нас.

Аналіз досліджень і публікацій останніх років. Процес та розвиток регіональної економічної інтеграції викликає зацікавленість у багатьох закордонних та вітчизняних вчених. Зокрема, дослідженням цього питання займалися Р. Болдвін, Г. Дугінець, О. Булатова, А. Філіпенко, В. Будкін, О. Шнирков, В. Муравйов, М. Кацин С. Маковський, В. Константінов та інші науковці.

Виділення невирішених раніше частин загальної проблеми. Однак, не зважаючи на доволі значний масив наукових праць на цю тематику, малодослідженим залишається сам процес зародження думки про регіональну економічну інтеграцію на європейських теренах та процес переходу від позиції політичної інтеграції до повноцінної правової інтеграції з поступовим утвердженням власної унікальної наднаціональної правової системи, а також делегацією державами наднаціональному судовому органу повноважень за її дотриманням.

Постановка завдання. Метою статті є висвітлення інтеграційного процесу, що відбувався на європейських теренах протягом XX століття та продовжується в XXI сторіччі, передумов виникнення думки щодо економічного інтеграційного об'єднання та процес його становлення. Україна має чітко розуміти, що є основою в процесі правової інтеграції до ЄС та які кроки було здійснено тими державами,

(C) Н. Ю. Климович, 2019 
що стали рушійною силою до об’єднання в ЄС, які повноваження вона має делегувати наднаціональним органам ЄС, а також причину виникнення потреби в такому делегуванні.

Виклад основного матеріалу дослідження. Сучасний світ розвивається досить інтенсивно і породжує нові тренди до глобалізації та економічної інтеграції. Глобалізація є рушійною силою до змін в різних аспектах суспільного життя людства. Процес глобалізації, що можна спостерігати протягом останніх десятиліть, викликає безліч дискусій. Особливо цікавими є такі прояви глобалізації як безпека розвитку економічних, соціальних, політичних та правових систем, проблеми глобальних трансформацій; більшість питань є досі суперечливими та потребують певного роду вирішення. Передумовами, або як їх ще можна назвати факторами, що обумовлюють економічну інтеграцію, є як політико-правові чинники, інфраструктурні, соціально-культурні, але найважливішими є насамперед саме економічні: довготривале економічне співробітництво між країнами, ступінь зрілості ринкових відносин, економіко-географічна близькість, наявність спільних економічних проблем, ресурсний та економічний потенціал можливого інтеграційного об’єднання. Саме ці фактори є визначальною рушійною силою, що спонукає країни до інтеграційного процесу, і саме це визначає характер майбутнього такого об'єднання. Тому на сьогодні існують переважно регіональні інтеграційні об’єднання економічного характеру.

Європа була та залишається прикладом для міжнародних трендів, це пов’язано з історичним розвитком, розвитком правової думки та прогресом ідеї до глобалізації. Після Першої світової війни на території європейського континенту зародились перші спроби до створення організацій, що мали б розв'язувати світові проблеми виключно в мирний спосіб [1]. Ліга Націй, заснована на Паризькій мирній конференції, була створена з метою розвитку співробітництва, досягнення миру, безпеки та процвітання народів. За час існування Ліги Націй було проведено велику кількість міжнародних форумів, що мали вплив на подальший розвиток міжнародного права стосовно аспектів пов'язаних з економічною інтеграцією. Одним з найбільш значущих форумів стала Міжнародна економічна конференція 1927 р., що відбулася в Женеві. Її можна вважати за перший форум дійсно глобального характеру, що був покликаний провести консультації з питань економічної політики як країн-членів так і країн, що не входили до складу Ліги Націй. Глобальний характер був підкреслений присутністю представників 50 країн та участю таких країн як Сполучені Штати Америки та СРСР. На форумі обговорили широкий спектр економічних проблем як міжнародного характеру, що відносилось до питань міжнародного співробітництва так і внутрішньодержавного, що містило розвиток різноманітних галузей промисловості. Ліга Націй виступила з пропозицією вдатися до взаємного скорочення країнами перешкод міжнародної торгівлі, а саме - торгових бар'єрів [2, с. 42]. На той час торговими бар'єрами виступали тарифні обмеження, тобто мито, та інколи сам експорт товарів. В резолюції форуму зокрема зазначалося, що питання пов'язане з митом, хоча і відноситься до питань суверенної юрисдикції держав, але зачіпає не лише виключно національні інтереси, а й має вплив на міжнародну торгівлю. Такий висновок поставив під питання «занадто вжива- 
ний протекціонізм», до якого вдавалися більшість країн того часу та дало поштовх до усвідомлення, що можливо досягнути значного покращення економічних умов шляхом збільшення можливостей міжнародної торгівлі. Було розроблено покроковий план досягнення результатів форуму, що стали визначальними для майбутнього економічної інтеграції. Фактично це стало прообразом системи Світової організації торгівлі (далі - СОТ). Відмінною особливістю конференції стало те, що вона вперше в історії констатувала шкоду, що її зазнає конкуренція в результаті демпінгу, та визнала право країн застосовувати захисні заходи проти такого явища задля захисту національної промисловості, створивши при цьому рекомендації та критерії при застосуванні таких заходів.

Ліга Націй займалася не лише конференціями пов' язаними з економічною інтеграцією, в планах Ліги Націй було також розробити модель створення такого роду інтеграційного об'єднання - Свропейського федеративного союзу. Один з найвизначніших політичних діячів Франції того часу А. Бріан виступив ініціатором плану інтеграційного об’єднання Європи. В 1927 р. Бріан на посту почесного голови Панєвропейського союзу він виступив у підтримку створення Сполучених Штатів Європи. Він розглядав об'єднання більше з точки політичної, аніж економічної чи правової. I саме політичні та громадські кола тогочасної Європи відгукнулись з найбільшою зацікавленістю на ідею Бріана. Результатом його звернення стало звернення представників європейських країн до Бріана підготувати проект створення федеративного зв’язку [3]. Проект дістав назву «Меморандум про організацію режиму Європейського федеративного союзу» та був представлений урядом Франції 17 травня 1930 р. Порівнюючи концепцію Європейського федеративного союзу та сучасний Свропейський союз можна прослідити певну схожість, особливо схожим є саме економічна модель; концепція загальноєвропейського ринку лягла в основу європейського внутрішнього ринку ЄС. А ось якщо брати політичну концепцію Європейського федеративного союзу то з сучасним Європейським союзом вона має мало спільного. Концепція інтеграційного об'єднання того часу не передбачала наднаціональності. В 1920-1930 рр. важко уявити ситуацію при якій уряд Франції чи будь-якої іншої країни Європи був готовий передати частину національного суверенітету та згодитися на створення наднаціональних структур. Тому цю концепцію не можна назвати занадто зрілою бо, як покаже надалі історія, регіональна економічна інтеграція не можлива без чіткого наднаціонального правового контролю і саме з цієї причині економічна криза 30 -х років минулого сторіччя та неузгодженість сторін щодо створення ефективного правового контролю згодом призведуть до нової великої війни в Свропі та пригальмують процес регіональної економічної інтеграції. Більша частина інтеграційних проектів в рамках Ліги Націй зазнали поразки з причини того, що значно випереджали свій час.

I хоча більшість інтеграційних проектів так і не було втілено в життя вони стали основою для подальших інтеграційних рухів, що захлиснули Європу та інші регіони світу після Другої світової війни. Вони стали основою для становлення сучасного інтеграційного права та дали основу визначенню та ознакам економічної інтеграції. Саме європейська інтеграція стала унікальним явищем для світового порядку. Вона мала за мету запобігти будь-яким майбутнім війнам на європейському 
континенті та забезпечити підживлення національних економік малих держав методом інтеграції в спільний глобальний ринок за допомогою інтернаціоналізації цих економік. Посиланнями до цього процесу стали утвердження в Європі політичної демократії, громадянського суспільства, соціальної відповідальності, верховенство права і закону, прав людини та утвердження принципу приватної власності. Якщо до цього етапу інтеграційні ідеї розвивалися лише на рівні певних політичних діячів та урядів, то в післявоєнний період ідеї інтеграції паралельно розвивалися як на урядовому рівні, так і на рівні суспільства.

В 1946 р. у своєму виступі в Цюрихському університеті Вінстон Черчилль окреслив ідеї всеєвропейського примирення та співпраці заради миру, що заклали основу інтеграційного процесу [4]. В цей самий час зароджуються суспільні рухи, що виступають за інтеграцію та об'єднання Європи в політичному плані, створення федеральної європейської конституції. Одним з таких рухів став створений в 1946 р. в Парижі Європейський союз федералістів, що досить швидко створив свої осередки в багатьох країнах Західної Європи. Бажанням федералістів було створити Європейську федерацію, якій пропонувалося передати певні суверенні права, необхідні для захисту спільних інтересів громадян країн-членів Європи, що містило питання міжнародного обігу грошових одиниць, зовнішньої політики та оборони. В травні 1948 р. відбувся з’їзд Конгресу Європи в Гаазі в якому взяло участь близько 700 делегатів, що виступали за об'єднання Західної Європи. Результатом конгресу стала підготовка проектів економічної та політичної інтеграції [5]. У січні 1948 р. вступив у дію договір про створення митного союзу Бенілюкс. Це був перший крок до економічної, політичної, соціальної та культурної інтеграції на теренах європейського континенту. А вже 5 травня 1949 р. у Лондоні відбулася зустріч провідних європейських країн, що започаткували Раду Європи. Рада Європи переслідувала за мету захист принципів свободи та правопорядку, в рамках якої було підготовлено Конвенцію про захист прав людини та основоположних свобод $1950 \mathrm{p}$.

Подальша еволюція економічної інтеграції на європейському континенті розвивалася досить стрімко. У 1950 р. міністр закордонних справ Франції Роберт Шуман озвучив ідею щодо примирення Франції та Німеччини шляхом економічної інтеграції. Цей процес трохи згодом отримав назву “план Шумана” і став першим кроком до створення Європейської федерації [6]. Ключовими моментами плану стало те, що він передбачав створення мирної об'єднаної Європи, але замість того щоб розпочати побудову з політичної складової напрочуд було вирішено, що політичній інтеграції мала передувати саме економічна та правова інтеграція. Це стало визначальним моментом у подальшій вдалій інтеграції, якої до цього моменту не могли досягнути методом політичних рішень. Саме в цей час поняття інтеграції потерпіло певних змін у визначенні та сприяло закріпленню ідеї того, що інтеграція розпочинається економічною складовою та надалі через створення правового механізму закріплюється на політичному рівні.

Ключовим моментом в інтеграційному процесі стало підписання Договору про Європейське об’єднання вугілля та сталі (далі - СОВС) 1951 р., що слугував створенню спільного ринку вугілля та сталі, передбачав швидку модернізацію та підвищення ефективності вугільної та металургійної галузі виробництва, покращення 
ефективності та умов праці. Фактично підпорядкування цих двох галузей наднаціональному органу дозволило покращити загальний стан економіки країн-членів та виключало можливість підготовки до війни якоїсь з країн-членів. Важливо зазначити, що в рамках $\mathrm{COBC} \mathrm{було} \mathrm{створено} \mathrm{декілька} \mathrm{інституцій} \mathrm{включаючи}$ Суд, наднаціональний орган, наділений правом приймати рішення та рекомендації. 27 березня 1957 р. країни-учасники ЄОВС зібралися в Римі задля підписання двох важливих інтеграційних договорів про заснування Європейської економічної спільноти (далі - ЄЕС) та Свропейської спільноти з атомної енергії (далі - Свратом) [7, с. 13-15]. Договір про заснування Європейської економічної спільноти став тим документом, що розпочав другий етап економічної інтеграції, а саме митний союз. Детально проаналізувавши ЄОВС можна дійти висновку, що це був той перший етап зі становлення зони вільної торгівлі. Саме ЄEC виник як результат еволюційного розвитку інтеграції до рівня митного союзу. ЄЕС мав за мету поступовий перехід до створення спільного ринку шляхом поступового скасування митних тарифів у торгівлі між країнами-учасниками та виробленням спільного митного тарифу на товари для торгівлі з іншими країнами. Але кінцевою метою ЄЕС була розробка принципу вільного обігу товарів, послуг, капіталу та фізичних осіб. Всі наявні на той момент інтеграційні об’єднання отримали нову спільну назву - Європейська сільнота.

Поступове скасування внутрішніх митних тарифів завершилася в 1968 р., було введено в дію Спільний зовнішній митний тариф. У 1970 р. ведення торговельної політики перейшло від компетенції національних органів до компетенції ЄЕС. Але торговельна політика не була єдиним пріоритетом для ЄЕС, багато зусиль було направлено й на інші сфери господарської діяльності країн-учасниць, наприклад, у 1958 р. було затверджено механізм ведення спільної сільськогосподарської політики. Було запропоновано кошти, отримані від застосування зовнішніх тарифів, направити на фінансування спільної аграрної політики, але Європейська спільнота була не готовим до таких радикальних кроків. Також ЄЕС вирішили не створювати зону вільної торгівлі між всіма європейськими країнами в рамках одного інтеграційного об’єднання, необхідно було створити дещо новий рівень інтеграції. Таким рішенням стало створення Європейської асоціації вільної торгівлі (далі - ЄАВТ) 4 січня 1960 р. в Стокгольмі [7, с. 15-18].

Період 1970-1980 рр. став періодом випробування на стійкість інтеграційного процесу. Крах бреттон-вудської валютної системи, що базувалася на золото-валютному стандарті, став потрясінням для економіки в усьому світі. Курс національних валют віднині мав визначатися згідно з ринковою кон'юнктурою. Країни-учасниці ЄEC, опинившись в тяжкій ситуації через проблеми здороження нафти, розробили план дій щодо диверсифікації виробництва результатом чого став перехід від тяжкої промисловості до більш технічно-наукових галузей нафтохімії та електротехніки. Це дозволило відновити економічний стан країн-учасниць та виробити механізм спільного подолання такого роду проблем, хоча цілісність інтеграції була під питанням, адже все більше учасників вдавалися до фактичного порушення Римських домовленостей у сфері нетарифних бар'єрів: субсидування власного виробництва, створення протекціоністських обмежень шляхом введення стандартів, 
імпортних ліцензій та інших процедурних моментів. Хоча органи ЄЕС засуджували таку практику не існувало механізму прямого втручання задля попередження чи врегулювання таких порушень зі сторони країн-учасниць. В результаті чого стало зрозумілим, що необхідно змінювати систему та переходити до етапу формування економічного та валютного союзу з подальшою трансформацією в політичну інтеграцію.

П’єр Вернер, прем’єр-міністр Люксембургу, виступив розробником плану, що дістав назву «план Вернера», метою якого було створення власної валютної системи, альтернативної бреттон-вудській. План передбачав спільну координацію бюджетної політики СЕС, обмеження допустимості коливання валют країн-учасниць та подальший перехід до єдиної валюти. Рада Європи, новостворений на той час орган, зайнялася створенням Європейської валютної системи в результаті чого в 1978 р. у Копенгагені було погоджено введення спільної кошикової валютної одиниці ЕКЮ. ЕКЮ використовувалась для міжнародних розрахунків як резервна валюта, а також ії використовували для ведення бюджету та статистики ЄЕС. На цьому етапі завершення формування економічного та валютного союзу не завершилося і тривало воно фактично до заснування Європейського союзу та введення спільної валюти - євро.

Європейський інтеграційний рух став настільки популярним, що до нього почали долучатися й інші країни. Економічна інтеграція стала настільки успішною, що виникло бажання повернутися до формату політичної інтеграції, що сприяло створенню в 1970 р. Європейського політичного співробітництва, відтепер ЄЕС став не лише певним локальним механізмом прийняття рішення, а й отримав міжнародне визнання. Відбулося правове визнання інтеграційного об'єднання на світовому рівні.

1986 р. став знаменним для ЄЕС бо було підписано Єдиний європейський акт (далі (ЄА), що проголошував ідею створення єдиного внутрішнього ринку товарів, послуг, капіталу та фізичних осіб до 31 грудня 1992 р. Цей документ закріпив юридичний статус Європейського політичного співробітництва, розширив сферу співпраці у багатьох напрямках, розширив повноваження Європейської Ради, Свропарламенту та Суду, було створено Суд першої інстанції. Одночасно зі створенням єдиного ринку було прийнято рішення в 1985 р. про створення Шенгенської зони, що мала за мету спростити переміщення осіб, стерти внутрішні кордони [7, с. 19-20].

Попередні кроки дали змогу в 1992 р. підписати Договір про заснування Європейського союзу (Маастрихтський договір), що набув чинності 1 листопада 1993 р. 3 цього моменту Європейська спільнота отримала нову назву - Європейський союз, що функціонує згідно з Договором про заснування ЄС та Договором про заснування ЄЕС. Європейський союз мав ввібрати в себе всі попередні інтеграційні здобутки включаючи економічну, де рішення вже приймалися наднаціональними органами та підлягали контролю Суду СС, та внутрішню і зовнішню політику. Договір також встановлював Економічний і монетарний союз включаючи механізм його роботи, правила розробки та реалізації спільної економічної політики, створив Європейський центральний банк (далі - ЄЦБ) та розробив критерії до вступу в монетарний союз. Амстердамський договір 1997 р., що набув чинності з 1 травня 1999 р. дещо доповнив Маастрихтський договір у сфері співробітництва в питаннях внутрішніх 
справ та юстиції: охорони зовнішніх кордонів, правового співробітництва з цивільних та кримінальних справ тощо. 31 січня 1999 р. було введено євро для безготівкових розрахунків, а з 1 січня 2002 р. євро було введено в готівковий обіг [7, с. 21-24].

3 погляду на подальше розширення Європейського союзу на країни Східної Європи у 2000 р. було підписано ще один договір - Ніццький. Він передбачав розширення повноважень Європарламенту, введення квот для участі країн в Європарламенті та Раді ЄС через механізм подвійної більшості (враховувалася не лише кількість країн, що голосували за те чи інше питання, а й кількість населення цих країн) [7, с. 26-27]. В результаті таких поправок було досягнуто згоди стосовно подальшого розширення Європейського союзу коштом країн Східної Європи. Європейський союз активізував свою міжнародну діяльність та почав претендувати на роль головного суб'єкту світової політики. Європейський союз продовжив підписання важливих міжнародних договорів із різними країнами та іншими інтеграційними об'єднаннями такими як АСЕАН та НАФТА. Завершенням формування Європейського союзу стало підписання Лісабонського договору 2007 р., що набув чинності 1 грудня 2009 р., що надав Європейському союзу статусу юридичної особи та наділив міжнародною правосуб'єктністю. Європейський союз отримав виключну компетенцію приймати законодавчі акти.

Європейський союз можна назвати найуспішнішим форматом інтеграційного об'єднання, адже він пройшов усі етапи формування та довів свою ефективність у вирішенні як внутрішніх так і зовнішніх питань. Наразі інші регіональні інтеграційні проекти знаходяться лише на шляху такого становлення, але модель Європейського союзу слугує зразком для побудови таких інтеграційних об'єднань у всьому світі й це дає можливість значно прискорити інтеграційні процеси в інших регіонах світу. Тому Україна вбачає своє майбутнє саме в участі у такому регіональному економічному об'єднанні як ЄС. Його механізм правового регулювання пройшов довгий процес становлення та розвитку і саме тому відбиває основні тренди розвитку міжнародного права. Саме стійка основа правового регулювання, що містить ефективне законодавство, що еволюціонувало протягом останніх 80 років, механізм чіткого контролю за виконанням з боку інтеграційних інституцій та можливість судового оскарження з боку фізичних та юридичних осіб в судовій інстанції, роблять $Є С$ настільки привабливим для прагнення інших держав стати членами $\mathrm{CC.}$

Отже, на сьогодні в суспільстві виникають численні дискусії щодо перспективності інтеграції України до ЄС, можливої довготривалості процесу приєднання, кількості тих пунктів плану щодо реалізації всіх формальностей. Так, процес інтеграції може затягнутися на декілька років, знадобиться багато сил задля приведення законодавства України у відповідність європейським нормам, але аналізуючи сам процес становлення регіонального інтеграційного об'єднання в Європі необхідно зазначити, що він тривав десятиліттями й був доволі непростим, країни Європи витратили на це багато сил, подолали безліч труднощів аби налагодити ідеальний механізм реалізації рішень в рамках інтеграційного об'єднання, створити дієве правове регулювання. I саме цей досвід Україна має використати аби стати повноправною частиною європейського інтеграційного об’єднання. Подальший шлях до 
інтеграції з боку України має базуватися на принципах переймання плодів інтеграційного процесу, а саме утвердження принципів вільної ринкової економіки, верховенства права та побудови механізму ефективного прийняття рішень.

Інтеграційний процес, як показують тренди, не є завершеним на даному етапі розвитку, бо надалі передбачається дещо інший інтеграційний етап - етап всесвітньої економічної інтеграції та стирання кордонів не лише в рамках одного конкретного регіону, а й у всьому світі. I саме тому досить важливим для України залишається питання не відставати від цих трендів, а йти в ногу з часом.

\section{Jimepamypa:}

1. Європейська інтеграція. Вікіпедія - вільна енциклопедія. URL: https://uk.wikipedia.org/wiki/ Європейська_інтеграція

2. Clavin P. Securing the world economy. The reinvention of the League of Nations 1920-1946. Oxford: Oxford University Press, 2013. $42 \mathrm{p}$.

3. EU Federalization : The Briand Plan. EU Funded Pro EU Troll. URL: https://eufundedproeutroll. wordpress.com/2014/06/07/eu-federalization-the-briand-plan/

4. Speech to the Academic Youth in Zurich. H20. URL: https://h2o.law.harvard.edu/text blocks/7599

5. The Congress of Europe in The Hague (7 to 10 May 1948). CVCE (Digital Research in European Studies). URL: https://www.cvce.eu/en/education/unit-content/-/unit/7b137b71-6010-4621-83b4b0ca06a6b2cb/4b311dc0-cbe6-421d-9f9a-3bc8b1b155f6

6. Robert Schuman : the architect of the European integration project. European Commission. URL: https://europa.eu/european-union/sites/europaeu/files/robert_schuman_en.pdf

7. European Union Politics (5th edn) 2016. Michelle Cini and Nieves Pérez-Solórzano Borragán. URL:http://www.oxfordpoliticstrove.com/view/10.1093/hepl/9780198708933.001.0001/hepl9780198708933-chapter-2

\section{Анотація}

Климович Н. Ю. Процес становлення міжнародно-правового регулювання регіональної економічної інтеграції Свропейського Союзу. - Стаття.

Статтю присвячено аналізу процесу становлення регіональної економічної інтеграції на європейських теренах, еволюції від політико-економічного до правового погляду на сутність інтеграційних процесів.

Ключові слова: інтеграція, регіональна економічна інтеграція, процес становлення регіональної економічної інтеграції.

\section{Аннотация}

Клилович Н. Ю. Процесс становления международно-правового регулирования региональной экономической интеграции Европейского Союза. - Статья.

Статья посвящена анализу процесса становления региональной экономической интеграции на европейских просторах, эволюции от политико-экономического к правовому взгляду на суть интеграционных процессов.

Ключевые слова: интеграция, региональная экономическая интеграция, процесс становления региональной экономической интеграции.

\section{Summary}

Klymovych $N$. Yu. The process of formation of international legal regulation of regional economic integration of the European Union. - Article.

The article is devoted to the analysis of the process of formation of regional economic integration in European territories, evolution from the political-economic to the legal point of view on the essence of integration processes.

Key words: integration, regional economic integration, process of formation of regional economic integration. 